\title{
Monitoring performance of a combined water recycling system
}

Holly Faye Castleton CEng, MIMechE

PhD Researcher, Department of Mechanical Engineering, The University of Sheffield, Sheffield, UK

Elizabeth Abigail Hathway PhD

Lecturer, Department of Civil and Structural Engineering, The University of Sheffield, Sheffield, UK
Edward Murphy CEng, MIMechE, MCIBSE

Technical Director, Mott MacDonald, Sheffield, UK

Stephen Bernard Marcus Beck PhD, CEng, FIMechE

Professor and Director of Learning and Teaching, Department of Mechanical

Engineering, The University of Sheffield, Sheffield, UK

Global water demand is expected to outstrip supply dramatically by 2030, making water recycling an important tool for future water security. A large combined grey water and rainwater recycling system has been monitored in response to an identified knowledge gap of the in-use performance of such systems. The water saving efficiency of the system was calculated at $-8.5 \%$ in 2011 and $-10 \%$ in 2012 compared to the predicted $36 \%$. This was due to a lower quantity of grey water and rainwater being collected than the system filter required to backwash alone. Top-up potable water was therefore required to complete the backwash process and flush WCs and urinals. The efficiency of the filter itself was calculated at $\mathbf{0 . 6 8}$, much lower than current figures used in grey water saving predictions. Using direct mains water with no recycling system would be more efficient in this case, highlighting the importance of realistic system analysis before future installations.

\section{Notation}

A

$f$

\section{$R$}

$V_{\mathrm{F}}$

$V_{\mathrm{R}}$

$V_{\mathrm{w}}$

roof collection area: $\mathrm{m}^{2}$

filter efficiency

annual average rainfall: $\mathrm{mm}$

volume of water required for flushing: $\mathrm{m}^{3}$

volume of water harvested: $\mathrm{m}^{3}$

volume of water collected from washing: $\mathrm{m}^{3}$ drainage efficiency

\section{Introduction}

The chief executive officer of the UK Carbon Trust announced in March 2013 that, 'business needs to wake up to water waste' (Delay, 2013). His news statement confirmed that by 2030 global water demand is expected to outstrip current supply by $40 \%$ (2030 Water Resources Group, 2009). Rainwater harvesting and grey water recycling systems offer the potential to replace some potable water used for toilet flushing and irrigation purposes with 'waste' water to make significant savings. However, despite a wide range of studies about grey water treatment techniques and recycled grey water quality, summarised by Pidou et al. (2007), there is a distinct knowledge gap as to how effectively these systems perform in practice, across both the UK and the rest of the world. This evidence gap is further apparent for systems that combine both grey water recycling and rainwater harvesting.

\subsection{Combined water recycling system performance}

Published research regarding combined grey water and rainwater recycling systems is limited. Studies have calculated potential water savings (amount of mains water saved) of $35 \%$ up to $80 \%$ for combined water recycling systems (Dixon et al., 1999; Ghisi and Ferreira, 2007). However, these are based on mathematical modelling and not monitored installations. Further work has focused on system water saving predictions, which do not take into account filtration system efficiencies, or represent in-use performance (Li et al., 2010). The most comprehensive study (Brewer et al., 2001) reports on the performance of a large combined rainwater, grey water and site groundwater reclamation system installed in a large visitor attraction in the $\mathrm{UK}$ as a demonstration system and research project. Each water source is subject to separate primary treatment and then combined for final treatment, outlined in Figure 1. Only a proportion of collected rainwater (from a $100000 \mathrm{~m}^{2}$ roof and surrounding hard ground) is recycled due to the limited size collection tank.

Half of the building water end use is for flushing toilets, all of which is provided by the reclaimed sources: groundwater $67 \%$; rainwater $22 \%$; grey water $11 \%$. Approximately $20 \%$ of the reclaimed water is used for filter backwashing (filtration stages highlighted in grey in Figure 1 require backwashing, with backwashed water sent to the drain). Systems that include grey water recycling require frequent backwashing, in which the backwash process itself consumes water. The balance of water used for backwashing against water saved is essential for assessing the efficacy of such a system. In this case only a small proportion of toilet flushing water has been provided by grey 
Engineering Sustainability

Volume 167 Issue ES3
Monitoring performance of a

combined water recycling

system

Castleton, Hathway, Murphy and

Beck

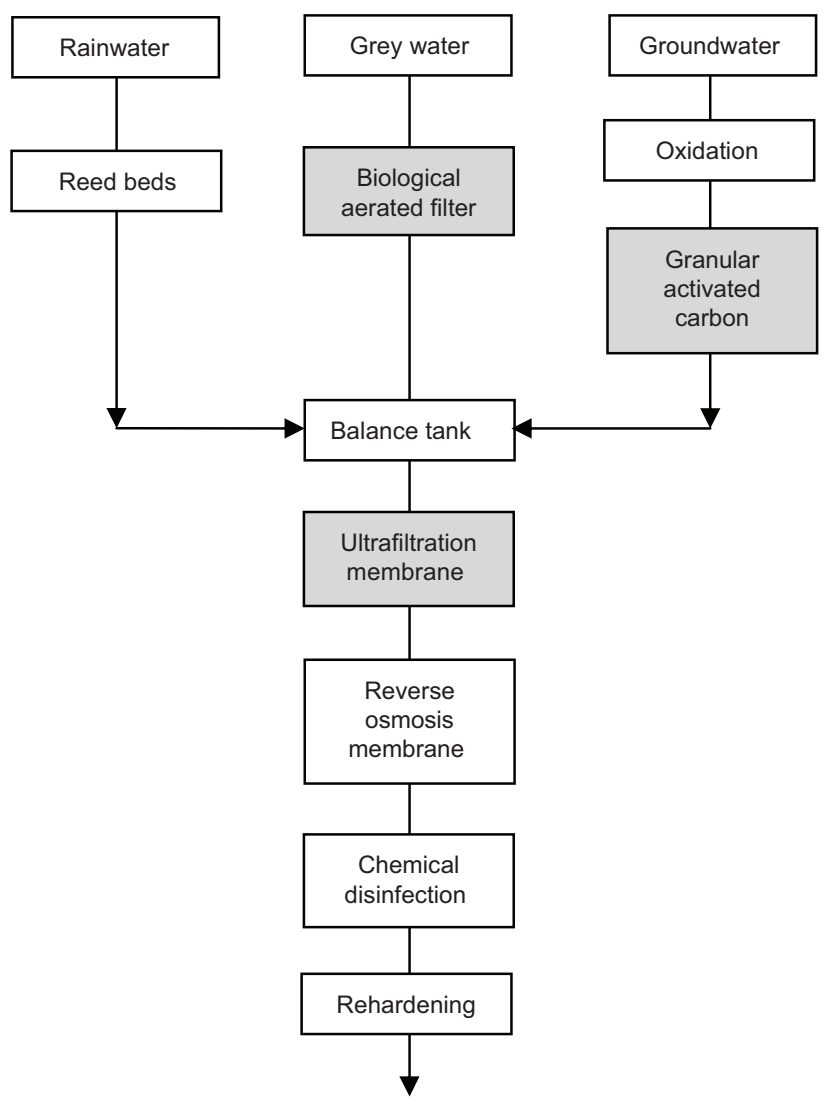

Figure 1. Schematic diagram of the combined water recycling system investigated by Brewer and colleagues, adapted from original schematic diagram (Brewer et al., 2001). The shaded boxes highlight parts of the system requiring backwashing water, but a significant proportion of filter backwashing is required for the grey water reuse.

Due to the limitation of further evidence for combined system operation, performance evidence has additionally been sought from individual grey water and rainwater recycling systems.

\subsection{Grey water recycling system performance}

Grey water (only) systems are more popular than combined systems in the UK, resulting in more performance-related studies. With the exception of Brewer et al. (2001), most research is again into performance prediction, not in-use case study monitoring. The majority of work has focused on residential systems, with the exception of a recent Environment Agency study in which a predicted $40 \%$ water saving was given for a large grey water recycling system in a $10000 \mathrm{~m}^{2}$ office building using a multimedia filter (EA, 2010). A summary of prominent grey water recycling performance studies is given in Table 1 , with water savings ranging from $5 \%$ to $100 \%$ reported.

A grey water system installed in a student halls of residence building (Brewer et al., 2001) incorporated a sand filter that was automatically backwashed approximately twice a week when a pre-set hydraulic resistance was met. When the system was designed, $10-20 \%$ of final treated water was expected to be used in the backwashing cycle (which goes to drain), but monitoring found the actual figure was $38 \%$ (coincidentally the same as the water savings of the system). This was attributed to higher than anticipated suspended solids. This suggests the assumption made by the Environment Agency (EA, 2010) of 95\% backwash filter efficiency is too high. Measured filter backwash efficiency has not been given in any other cited study.

\begin{tabular}{|c|c|c|c|c|}
\hline Study & Performance calculation method & Building type & Country & Water savings \\
\hline EA $(2010$ & Not given, approximation assumed & $\begin{array}{l}80 \text { room hotel } \\
10000 \mathrm{~m}^{2} \text { office } \\
\text { Secondary school }\end{array}$ & UK & $\begin{array}{l}98-100 \% \text { (hotel) } \\
40 \% \text { (office) } \\
12 \% \text { (school) }\end{array}$ \\
\hline EA (2000) & Not given & Residential & UK & $5-36 \%^{a}$ \\
\hline Li et al. (2010) & Not given, approximation assumed & Domestic & Ireland & $100 \%$ \\
\hline Brewer et al. (2001) & Monitored case study & Domestic (3 beds) & UK & Not operating \\
\hline Brewer et al. (2001) & Monitored case study & Domestic (5 beds) & UK & $\begin{array}{l}54 \% \\
\text { (extrapolated } \\
\text { from } 1 \text { month) }\end{array}$ \\
\hline Brewer et al. (2001) & Monitored case study & Student halls of residence & UK & $38 \%$ \\
\hline
\end{tabular}

${ }^{a} A$ later report $(E A, 2007)$ advises maximum savings may be closer to $20 \%$ due to lower toilet water consumption in newer properties.

Table 1. Summary of grey water recycling system performance studies 


\begin{tabular}{|c|c|c|c|c|}
\hline Study & Calculation method & Building type & Country & Water savings \\
\hline Brewer et al. (2001) & Monitored case study A & $1500 \mathrm{~m}^{2}$ office & UK & $40 \%$ \\
\hline Brewer et al. (2001) & Monitored case study B & 3-storey office/showroom & UK & $\begin{array}{l}\text { 1. } 22 \%^{\mathrm{a}} \\
\text { 2. } 64 \%^{\mathrm{b}}\end{array}$ \\
\hline Chilton et al. (2000) & Monitored case study & Supermarket & UK & $21 \%$ \\
\hline Mun and Han (2012) & $\begin{array}{l}\text { Monitored case study to } \\
\text { validate model }\end{array}$ & Dormitory complex & South Korea & $60 \%{ }^{c}$ \\
\hline Ward et al. (2012) & Monitored case study & Office building & UK & $87 \%$ \\
\hline
\end{tabular}

${ }^{a}$ Original system.

${ }^{b}$ Modified catchment area, recorded over winter months, may be optimistic.

Includes disrupted rainwater supply due to pumping problems.

Table 2. Summary of non-domestic, monitored, rainwater harvesting system case studies

\subsection{Rainwater harvesting system performance}

Rainwater harvesting systems are more widely reported in the literature. However, Ward et al. (2012) highlight that even for rainwater systems, little knowledge of empirical performance assessments exists. They provide a summary of recent rainwater harvesting performance studies, predominantly domestic, which show water savings of $22-70 \%$ for in-use case studies. The only commercial example has a water saving of $59 \%$. A summary of further non-domestic monitored case studies for rainwater harvesting is given in Table 2, showing water savings of between $21 \%$ and $87 \%$.

Rainwater is generally treated by filtration in conjunction with disinfection (Brewer et al., 2001; Chilton et al., 2000; Mun and Han, 2012), with no need for a filter backwash system. Rainfall, collection efficiency, collection area and storage volume are commonly considered as the main parameters in determining system efficiency. For an office/showroom building, a water saving of $72 \%$ was predicted, but an inefficient catchment area and leaks from downpipes led to lower measured results (Brewer et al., 2001). Chilton et al. (2000) reported an actual collection efficiency of $51 \%$, but only $21 \%$ was achieved due to the limited size of collection tank. Mun and Han (2012) applied a collection factor of 0.9 for the roof collection and a further 0.9 for the filter, based on literature and manufacturer data.

\subsection{UK grey water and rainwater regulations}

Two British standards have been published for water recycling in the UK: BS 8515:2009 (BSI, 2009) for rainwater harvesting systems and BS 8525-1:2010 (BSI, 2010) for grey water recycling systems, covering design, installation, alteration, testing and maintenance. In terms of treatment, it is stated that collected grey water should only be treated to the extent needed to meet water quality guidelines of the application being supplied (BSI, 2010). The grey water used should present no undue risk to health, but currently there is 'no specific regulatory requirement for water quality that apply to systems which use grey water for non-potable water use' (BSI, 2010). For rainwater reuse, 'filtration should be incorporated in the system before the collected rainwater enters the main body of stored water, to prevent debris accumulating in the tank' (BSI, 2009). The filter should have an efficiency of at least $90 \%$ (BSI, 2009).

\subsection{Typical office water consumption}

To quantify and assess the potential for water recycling in a building it is necessary to consider how much, and where, water is used. For a new build design this value is often taken from benchmarks. The research presented in this paper is conducted at a large office building; therefore Table 3 outlines three differing benchmarks for office water consumption in the UK.

In 1998 the average office-based business in the UK reportedly used $63 \%$ of total water consumption for toilet and urinal

\begin{tabular}{llc}
\hline Study & $\begin{array}{c}\text { Typical: } \mathrm{m}^{3} / \\
\text { person per year }\end{array}$ & $\begin{array}{c}\text { Best practice: } \mathrm{m}^{3} / \\
\text { person per year }\end{array}$ \\
\hline EA (2013) & $9 \cdot 3$ & $6 \cdot 4$ \\
$\begin{array}{l}\text { Waggett and Arotsky } \\
\text { (2006) }\end{array}$ & $7 \cdot 2^{\mathrm{a}}$ & $4 \cdot 8^{\mathrm{a}}$ \\
Defra (2010) & $5 \cdot 6$ (new build & $3 \cdot 0$ (target) \\
& or refurbished) & \\
\end{tabular}

a Based on an occupancy density of $12 \mathrm{~m}^{2} /$ person.

Table 3. UK office water consumption benchmarks 
Engineering Sustainability

Volume 167 Issue ES3
Monitoring performance of a

combined water recycling

system

Castleton, Hathway, Murphy and

Beck

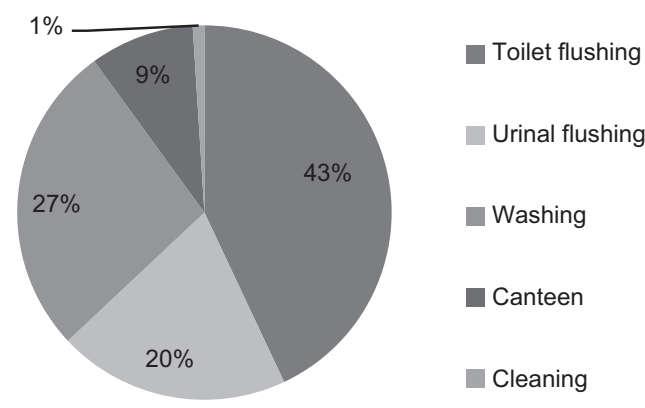

Figure 2. Typical UK office-based business water end-use breakdown (1998). Numbers taken from Shouler et al. (1998)

flushing (Shouler et al., 1998) (Figure 2). Water used for washing $(27 \%)$ and cleaning $(1 \%)$ could be collected and recycled to replace some potable water currently used for flushing. Water from catering is generally not collected as it is contaminated with fats and grease and will block filtration systems. Despite several available sources of domestic water end-use benchmarks (Butler and Memon, 2006) there is a distinct lack of similar benchmarks for offices. No calculation method or sample details were given for the benchmark breakdown presented in Figure 2, although the figures are still widely used - for example, South Staffordshire Water (2013). In offices, more frequent inclusion of showers, low-flow taps, low-flush toilets and waterless urinals in recent years may have had an effect on this breakdown. Brewer et al. (2001) noted that $57 \%$ less water per person was consumed in the monitored case study office with installed water-efficient appliances $(58 \%$ used for flushing and only $8 \%$ for hand washing) than in the monitored office with standard appliances. Hills et al. (2002) recorded an end-use breakdown of 48\% flushing WCs, $7 \%$ flushing urinals, $13 \%$ hand washing, 32\% cleaning and canteen use for a national visitor centre with low-flow appliances. The percentage of water used for hand washing has decreased, indicating a reduction in grey water availability for re-use. The proportion between water used for flushing and hand washing, however, may be expected to remain relatively constant.

\subsection{Study aims}

A water recycling system installed in a UK office building that combines both grey water and rainwater has been monitored for a period of 2 years. Due to the scarcity of combined water recycling operational evidence, the first aim of this study was to provide performance evidence of the system. The system was installed to realise potable water savings by flushing toilets and urinals with the recycled water. A comparison was therefore also made between the predicted and actual water saving efficiency of the system. Due to a lack of up-to-date water consumption benchmarks and end-use breakdown, further analysis was additionally conducted to compare the total building water consumption to current benchmark figures and end-use breakdown found in the literature.

\section{Case study description}

This section describes the design and operation of the combined grey and rainwater recycling system that has been monitored for this research.

\subsection{Water recycling system description}

A schematic diagram of the case study combined water recycling system is shown in Figure 3. There are two pulsed output water meters installed: on the grey water and rainwater supply for flushing (combined) (M2), and the potable cold water system top-up supply (how much potable water the water recycling system is using) (M1). The water meters are linked to the building management system. The building management system has the capability to record water consumption data every half hour, but unfortunately the data logging function was not working correctly. Physical meter readings were instead used to collect meter data.

A pulsed output water meter is installed on the main incoming water supply into the building to monitor the total mains cold water consumed within the building (WM). This directly supplies a potable cold water storage tank, from which a boosted water supply feeds the appliances (excluding WCs and urinals) within the building, the hot water boilers, and the water recycling post-treatment storage tank that feeds all WCs and urinals. This provides a top-up supply in the event of flushing demand exceeding recycled grey and rainwater supply.

The recycling system reuses the waste water from the wash basins and showers in the central core area, and the rainwater collected from the bottom of the light well. A total of 68 wash hand basins, 11 showers and a cleaners' sink supply the system. These connect into two main discharge pipes that join together along with the rainwater collected from the atrium collection space before supplying the $4 \mathrm{~m}^{3}$ grey water pretreatment tank. An additional 30 wash hand basins, eight showers and eight cleaner sinks are not connected to the system, peripherally located in the building or situated on the ground floor.

Both grey water system tanks are located in the water tank plant room. From the pretreatment tank, grey water is drawn into a multimedia filter, where the major impurities and debris are removed. The filter/backwash pump set then transfers the water into the main $8 \mathrm{~m}^{3}$ storage tank. An integrated backwash function periodically uses recycled grey water from the main storage tank to clean the filter, which is discharged to the drain. The main tank has a central divider to ensure the water supply to the building is uninterrupted while maintenance tasks are carried out. From the grey water storage tank, a booster set 


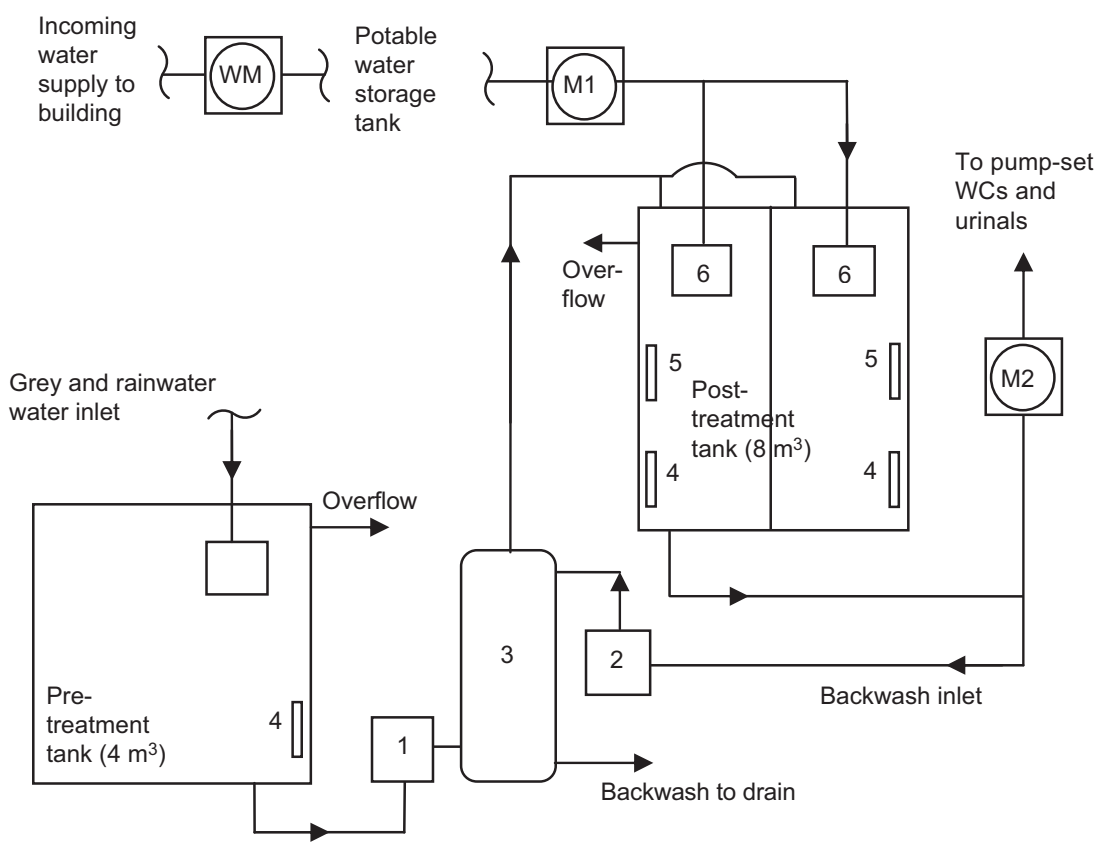

\begin{tabular}{|c|l|c|l|l|l|}
\hline 1 & Filter pump & 3 & Multimedia filter & 5 & High-level float switch \\
\hline 2 & Backwash pump & 4 & Low-level float switch & 6 & Float level \\
\hline - & Pipe route & \multicolumn{4}{|l}{} \\
\hline
\end{tabular}

Figure 3. Schematic diagram of case study combined water recycling system. $\mathrm{M} 1$ and $\mathrm{M} 2$ indicate the two system-specific water meters

takes the water to the WCs and urinals throughout the building.

The system has been operational since 2008. There is a planned and regular maintenance programme in place to keep the system operating as recommended by the system supplier. The storage tanks are cleaned once a year and weekly water samples are tested for bacteria levels.

\subsection{Filter operation and backwash system}

The multimedia filter allows faster build-up of biomass when compared to other conventional treatment methods, with each media layer decreasing in pore size. As such is it possible to restore the filters by backwashing, with the assistance of a jet of compressed air where filter separation is necessary. The pressure difference across the filter is calculated using two pressure sensors. Backwashing can be set to occur when the pressure difference reaches $7 \mathrm{psi}$, or based on a time override setting. To prevent over-clogging of the filters, the time setting has been used so that the system backwash process occurs every $48 \mathrm{~h}$. The water is drained from the filter and the air diffuser operates for $5 \mathrm{~min}$. Subsequently the backwash pump delivers recycled water from the main storage tank at $27 \mathrm{~m}^{3} / \mathrm{h}$ to remove the now separated solids from the filter media. The backwash pump runs for approximately $15 \mathrm{~min}$.

Initially an element of the filter was designed to kill bacteria in the recycled water but this did not work as expected and subsequent thickening of the recycled water caused the entire system to require purging with hypochlorite. As a result, the water is now disinfected by regular automated dosing of hypochlorite. The viewing window into the filter confirms that the filter is now clear of significant bacterial/biomass build up.

\section{Methodology}

The performance of the installed system was initially predicted, to understand what water saving efficiency may have been expected at the design stage, and to allow comparison between predicted and actual performance of the system. A monitoring programme of the system water meters was then conducted to 
Engineering Sustainability

Volume 167 Issue ES3
Monitoring performance of a

combined water recycling

system

Castleton, Hathway, Murphy and

Beck record in-use water consumption data for the system, and to enable the system water saving efficiency and filter efficiency to be calculated.

\subsection{System performance prediction}

The installed building sanitary fittings are all low flow and low flush and the target water consumption was $3.42 \mathrm{~m}^{3} /$ person per year at the building design stage. The building was originally designed for approximately 1000 staff, giving a design stage estimated annual water consumption prediction of $3420 \mathrm{~m}^{3}$. Occupancy has been monitored throughout the study period by the collection of security access data and information from building management staff. Only minor changes in building occupant numbers have been observed; however, the total was lower than the original design occupancy. Based on the security data average daily occupancy throughout the study period was calculated at approximately 600 , taking account of daily variation including part-time workers.

Based on this occupancy of 600 , a revised expected annual water consumption becomes $2053 \mathrm{~m}^{3}$. Using the end-use breakdown presented in Figure 2 (28\% for washing and cleaning), and the proportion of wash hand basins in the building that feed the system $(79 \%)$, an estimated maximum of $409 \mathrm{~m}^{3}$ grey water could be recovered by the system by Equation 1, where $V_{\mathrm{w}}\left(\mathrm{m}^{3}\right)$ is the volume of water collected from washing $(0.28 \times 0.79 \times 2053)$ and $f$ represents the filter efficiency. A filter efficiency of 0.9 was used for this case (Brewer et al., 2001; EA, 2010) due to manufacturers' data often being used in the design stage estimation process. In reality, based on the literature reviewed in Sections 1.2 and 1.3 actual filter efficiency is expected to be lower.

\section{Estimated collected grey water $=V_{\mathrm{w}} \times f$}

Rainwater is collected from the surface area of a glass light well included at the centre of the building. The collection area, $A$, is approximately $140 \mathrm{~m}^{2}$. Annual average rainfall, $R$, for Sheffield (1981-2010) is given by the UK Met Office (2011) as $80-100 \mathrm{~cm}$. According to Equation 2 (EA, 2007), the estimated potential annual rainfall collection is $56 \cdot 7 \mathrm{~m}^{3}$. This assumes a drainage efficiency, $\phi$, of 0.50 based on a flat tiled roof (EA, 2007) and filter efficiency factor, $f$, of 0.9 based on previous values used in the literature (Chilton et al., 2000; EA, 2007; Palla et al., 2011).

\section{Estimated collected rainfall $=R \times A \times \phi \times f$}

This demonstrates that the combined system was expected to be grey water led, with rainwater contribution of only $12 \%$. The combined system is estimated to have a maximum water saving efficiency of $39 \%$ using Equation 3, where $V_{\mathrm{R}}\left(\mathrm{m}^{3}\right)$ is the volume of water harvested (assuming an infinite reservoir), and
$V_{\mathrm{F}}\left(\mathrm{m}^{3}\right)$ is the volume of water required for flushing (Dixon et al., 1999).

3. Water saving efficiency $(\%)=\frac{V_{\mathrm{R}}}{V_{\mathrm{F}}} \times 100$

\subsection{Water flow monitoring}

In order to determine the in-use operation of the system, it was monitored for a period of 2 years from 1 January 2011 to 31 December 2012. This predominantly involved the regular collection of water meter readings from the in situ water meters shown in Figure 3 (WM, M1 and M2). Meter readings were taken by the main author on the first working day of every month at 0700 hrs by reading the direct-display number $\left(\mathrm{m}^{3}\right)$ shown on the face of each meter.

The recorded water quantity used for flushing (M2) includes any additional potable water the system required to operate. This additional potable water used in the system is also monitored (M1). The total quantity of grey water and rainwater used in the building has therefore been calculated from M2-M1. The water saving efficiency of the system was then calculated for 2011 and for 2012 using Equation 3.

Regular communication throughout the study period with the facilities management staff at the building was maintained in order to determine any known system functionality issues. However, no operational issues with the system itself were reported.

\subsubsection{Monitoring limitations}

There are some limitations with the monitoring of the system as not all water flows are individually metered. The overall collected grey and rainwater (into the pretreatment tank) and the quantity of overflow are unknown as they are not metered for water flow. In an attempt to understand more about the system operation (further to the measured water flows), the quantity of grey and rainwater that has been collected by the system, and how much is used by the filter backwash process, have been estimated.

\subsubsection{Calculating grey and rainwater potential yield}

Rainfall data were obtained from annual meteorological weather data for Leopold Street, Sheffield city centre (Weather Analytics, 2012), less than $1000 \mathrm{~m}$ from the building site. This provided hourly recorded weather variables for the entire monitoring period (2011 and 2012). The annual collected rainfall has been estimated using Equation 2, excluding filter efficiency as unknown at this stage.

The potential volume of collected grey water $\left(\mathrm{m}^{3}\right)$ has been calculated as follows, excluding filter efficiency as unknown at this stage. 


\begin{tabular}{lccccc} 
& \multicolumn{2}{c}{2011} & & 2012 \\
\cline { 2 - 4 } \cline { 5 - 5 } & Predicted & Actual & & Predicted & Actual \\
\hline Building water use: $\mathrm{m}^{3}$ & 2053 & 8465 & & 2053 & 7984 \\
Building water use per person: $\mathrm{m}^{3}$ /person & $3 \cdot 42$ & $14 \cdot 1$ & & $3 \cdot 42$ & $13 \cdot 3$ \\
M2, Water used for flushing: $\mathrm{m}^{3}$ & 1293 & 4514 & & 1293 & 3899 \\
M1, Potable top-up: $\mathrm{m}^{3}$ & 827 & 4898 & & 827 & 4288 \\
Water saving efficiency: $\%$ & 36 & $-8 \cdot 5$ & & 36 & -10 \\
Annual rainfall: $\mathrm{cm}$ & $80-100$ & 86 & $80-100$ & 141
\end{tabular}

Table 4. Recorded building and water recycling system water consumption

Actual building water consumption $\left(\mathrm{m}^{3}\right) \times$ Proportion of water used for hand washing and cleaning $(\%) \times$ Proportion of fitting connected to the water recycling system (\%).

\subsubsection{Calculating filter backwash water requirement}

The annual water requirement $\left(\mathrm{m}^{3}\right)$ for the filter backwash process has been calculated as

Hours of operation $(\mathrm{h}) \times$ Backwash process flow rate $\left(\mathrm{m}^{3} / \mathrm{h}\right)$.

\section{Results and discussion}

The measured building water consumption is reported in Table 4 . The building performs poorly for water consumption $\left(13.3 \mathrm{~m}^{3} /\right.$ person per year) when compared to benchmark figures, using about $45 \%$ more than the typical office consumption given by the Environment Agency $\left(9.3 \mathrm{~m}^{3} /\right.$ person), and also $45 \%$ more than that in case study $\mathrm{B}$ (Table 2), a monitored low-flow water fitting office of 10 occupants $\left(9 \mathrm{~m}^{3} /\right.$ person, extrapolated from given data) (Brewer et al., 2001). Showers and a staff canteen are, however, not present in case study B, which could account for the higher water usage. As the building contains low-flow and low-flush fittings throughout, it should be performing closer to best practice benchmarks, which are much lower still at 3.0-6.4 $\mathrm{m}^{3} /$ person.

The actual building water use per person is four times larger than that originally predicted. Approximately half the building water usage was for toilet and urinal flushing in the study period, decreasing slightly from 53\% in 2011 to $49 \%$ in 2012 . This is lower than the $63 \%$ designated for flushing by the benchmark breakdown (Figure 2) and 58\% recorded for case study B (Brewer et al., 2001). Figure 4 shows the monthly variation of water consumption in the building compared to that used for flushing. The proportion used for flushing remains relatively constant around the $50 \%$ mark. The total building consumption varies throughout the year, with higher consumption generally seen across summer and autumn months, where flushing accounts for slightly less of the total water consumption. The large staff canteen and the addition of

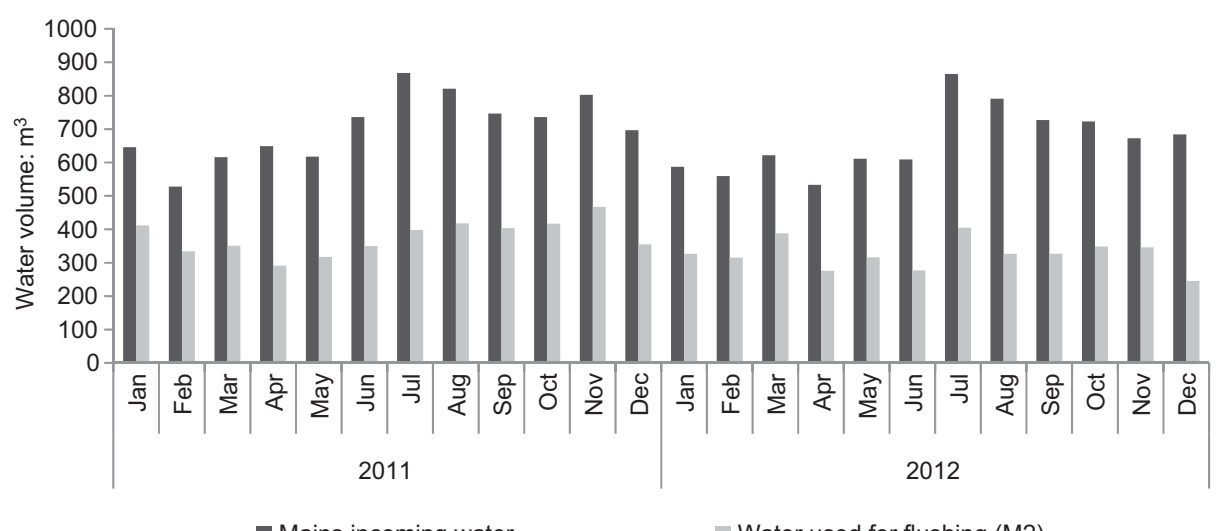

Figure 4. Monthly variation of total building water consumption compared to water volume used for flushing 


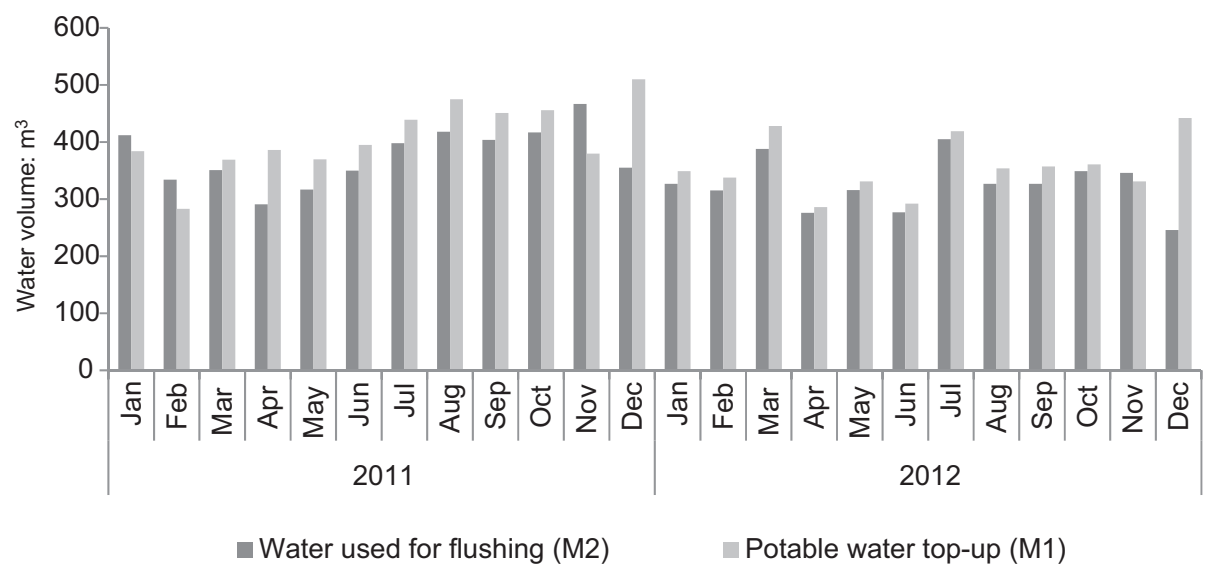

Figure 5. Quantity of water used for flushing and mains top-up required for case study system throughout 2011 and 2012

showers compared to case study B (58\% flushing, low-flush toilets), would account for the lower proportion used for flushing in this building.

\subsection{Water saving efficiency}

The water saving efficiency of the system is negative, calculated at $-8.5 \%$ for 2011 and $-10 \%$ for 2012 , based on measured water consumption of the water recycling system presented in Table 4 . The negative efficiency shows that the system is using more potable top-up water than it is providing for flushing. This means that the direct use of potable water would in this case be more efficient than using the installed recycling system. Figure 5 provides the monthly system water consumption breakdown. This shows that in only 4 months (January, February, November 2011 and November 2012) was a water saving made. December has the largest notable difference between water used for flushing and top-up water required. A subsequent interview with the facilities management staff about poor system performance indicated that the excessive potable water consumption may be due to a combination of low volumes of hand washing water available and the system's backwash system.

\subsection{Grey water potential yield (2012)}

An initial annual estimate of $409 \mathrm{~m}^{3}$ was made for potential collected grey water quantity based on $28 \%$ hand washing and cleaning (1998), $79 \%$ of fittings in the building connected and annual building water consumption of $2053 \mathrm{~m}^{3}$. Studies identified in Section 1.1 have since recorded an average of $10 \cdot 5 \%$ end water use for hand washing due to low-flow fittings. As an end-use breakdown, this negates the need to include the percentage of people who do use the hand washing facilities, observed by Hills et al. (2002) as $83 \%$ of women and $73 \%$ of men. Using the actual building water consumption $7984 \mathrm{~m}^{3}$, and taking $11 \cdot 5 \%$ (low-flow hand washing $10 \cdot 5 \%$, and cleaning $1 \%$ ), this gives a revised grey water yield of $725 \mathrm{~m}^{3}$, ignoring filter efficiency factor as an unknown and noting only $79 \%$ of fittings are connected to the system.

\subsection{Rainwater potential yield (2012)}

In 2012 total rainfall was recorded at $141 \mathrm{~cm}$, higher than the average used in design, and would provide a total of $99 \mathrm{~m}^{3}$ of water to the system, using Equation 2. Despite the high rainfall year, this is still a small proportion of the potentially collected water at $13 \%$.

Figure 6 shows the correlation between monthly rainfall and the amount of additional potable water required by the system above flushing (M1-M2). A negative correlation would be expected if rainfall were influencing system performance but this is not clearly recognised, as expected from the low potential collection proportion of rainwater compared to grey water. The months of highest rainfall do not directly correlate

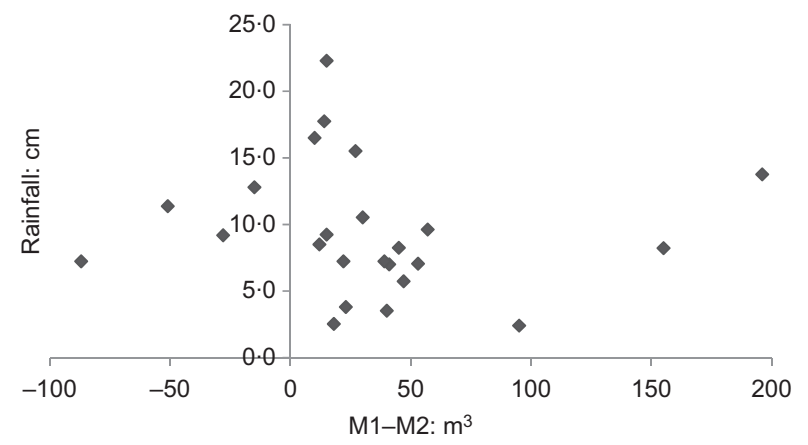

Figure 6. Monthly rainfall for Sheffield plotted against M1-M2 
Engineering Sustainability

Volume 167 Issue ES3
Monitoring performance of a

combined water recycling

system

Castleton, Hathway, Murphy and

Beck with the months in which the collected water exceeds the potable water used (negative values).

\subsection{System backwash impact}

The backwash process in this system runs every $48 \mathrm{~h}$ for $15 \mathrm{~min}$ at $27 \mathrm{~m}^{3} / \mathrm{h}^{1}$ with the backwashed water taken from the treated grey and rainwater and discharged straight to the drain. This equates to an annual backwash water consumption of $1232 \mathrm{~m}^{3}$. With a combined grey and rainwater potential yield of $824 \mathrm{~m}^{3}$ (based on monitored data and before filtering) for 2012, an estimated additional $408 \mathrm{~m}^{3}$ of potable top-up water would be required just for filter backwashing, before any water is provided for flushing. This explains the negative water saving efficiency figures obtained and gives an estimated potable water top-up requirement of $4307 \mathrm{~m}^{3}$, which compares well with that recorded at $4288 \mathrm{~m}^{3}$.

\subsection{System filter efficiency}

It is not possible to calculate an accurate filter efficiency factor in terms of collected rain and grey water because of the meter locations. However, in relation to total water used for flushing in the building, a backwash filter efficiency of 0.68 is realised. This compares with a previously monitored case study in which the backwash process had an actual filter efficiency factor 0.62 , compared with the $0 \cdot 8-0 \cdot 9$ expected (Brewer et al., 2001). From the literature reviewed in conjunction with the results from this study, the efficiency of grey water filters that require backwashing should be carefully considered when estimating future system water savings. Rainwater-only systems are not affected as backwashing is not commonplace.

\section{Conclusions}

There is a knowledge gap concerning the actual measured performance of grey water recycling and combined rainwater and grey water recycling systems, particularly in comparison to performance predictions. This research has provided performance evidence from a monitored combined rainwater and grey water system installed in a large $\left(13500 \mathrm{~m}^{2}\right)$ office building. The system performs poorly as confirmed by a calculated negative water saving efficiency of $-8 \cdot 5 \%$ to $-10 \%$. It should, however, be noted that this is a study of a single system and is not representative of all combined water recycling systems. The predicted savings for the case study system were positive at a maximum $36 \%$ savings. The poor monitored performance is, however, likely to be due to design flaws, which should be avoided in future work.

Due to low volumes of collected grey water compared to that required for flushing and a small, inefficient rainwater collection area (small and flat), not enough water is collected to fulfil even the filter backwash water use. The system therefore uses potable top-up water to provide the building's toilet and urinal flushing requirements, in addition to extra potable water required to complete the backwash water requirement. In this particular case it would be more efficient to bypass the recycling system and directly use potable water for flushing.

When filter efficiency is accounted for in previous grey water system performance predictions, values of 0.9 and 0.95 have typically been used. The filter efficiency has been calculated in this case at 0.68 , which is similar to a filter efficiency of 0.62 determined in a previous study (Brewer et al., 2001). This inuse evidence suggests a lower, more realistic filter efficiency should be employed in future grey water recycling system performance prediction, when a backwash process is required. This study has further highlighted the need for detailed system analysis and realistic water saving predictions of combined water recycling systems before inclusion within buildings, to ensure savings can be realised.

In addition, the actual building water use per person is four times larger than that originally predicted. The given benchmark indicates $63 \%$ of water in offices is used for flushing, but the actual end-use water consumption recorded for flushing was an average of $51 \%$ for the 2-year study period. There is a lack of office water evidence-based end-use benchmarks available, with the most relevant dating back to 1998, which does not reflect the introduction of low-flow and flush fittings conventionally installed in current buildings.

\section{Acknowledgements}

This research was funded by the Engineering and Physical Sciences Research Council (EPSRC) (grant reference number $\mathrm{EP} / \mathrm{G} 037477 / 1)$ and conducted as part of the E-Futures DTC at the University of Sheffield.

\section{REFERENCES}

Brewer D, Brown R and Stanfield G (2001) Rainwater and Greywater Use in Buildings: Project report and case studies. Building Services Research and Information Association (BSRIA), Bracknell, UK.

BSI (2009) BS 8515:2009: Rainwater harvesting systems. Code of practice. BSI, London, UK.

BSI (2010) BS 8525-1:2010: Grey water systems. Code of practice. BSI, London, UK.

Butler D and Memon FA (2006) Water consumption trends and demand forecasting techniques. In Water Demand Management. IWA Publishing, London, UK.

Chilton JC, Maidment GG, Marriott D, Francis A and Tobias G (2000) Case study of a rainwater recovery system in a commercial building with a large roof. Urban Water 1(4): 345-354.

Defra (Department for Environment, Food and Rural Affairs) (2010) Water Consumption in New Builds. See http://sd.defra.gov.uk/ progress/soge/performance-data-2010/target-areas/waterconsumption-new-builds (accessed 11/04/2013). 
Engineering Sustainability

Volume 167 Issue ES3
Monitoring performance of a

combined water recycling

system

Castleton, Hathway, Murphy and

Beck
Delay T (2013) Why business needs to wake up to water waste. See http://www.carbontrust.com/news/2013/03/whybusiness-needs-to-wake-up-to-water-waste (accessed 10/04/ 2013).

Dixon A, Butler D and Fewkes A (1999) Water saving potential of domestic water reuse systems using grey water and rainwater in combination. Water Science and Technology 39(5): 25-32.

EA (Environment Agency) (2000) A Study of Domestic Grey Water Recycling. Environment Agency, Bristol, UK.

EA (2007) Conserving Water in Buildings, Chapter 7 - Reusing Grey Water and Harvesting Rainwater. See http://test. environment-agency.gov.uk/static/documents/Leisure/ cwb_ch7_grey_rain_889316.pdf (accessed 10/04/2013).

EA (2010) Energy and Carbon Implications of Rainwater Harvesting and Grey Water Recycling. See https://www.gov. uk/government/uploads/system/uploads/attachment_data/ file/291745/scho0610bsmq-e-e.pdf (accessed 10/04/2013).

EA (2013) How Much Water Should We Be Using? See http:// test.environment-agency.gov.uk/business/topics/water/ 34866.aspx (accessed 26/05/2014).

Ghisi E and Ferreira DF (2007) Potential for potable water savings by using rainwater and grey water in a multi-storey residential building in southerm Brazil. Building and Environment 42(7): 2512-2522.

Hills S, Birks R and McKenzie B (2002) The Millenium Dome 'Watercycle' experiment: to evaluate water efficiency and customer perception at a recycling scheme for 6 million visitors. Water Science and Technology 46(6-7): 233-240.

Li Z, Boyle F and Reynolds A (2010) Rainwater harvesting and grey water treatment systems for domestic application in Ireland. Desalination 260(1-3): 1-8.

Mun JS and Han MY (2012) Design and operational parameters of a rooftop rainwater harvesting system: definition, sensitivity and verification. Journal of Environmental Management 93(1): 147-153.

Palla A, Gnecco I and Lanza LG (2011) Non-dimensional design parameters and performance assessment of rainwater harvesting systems. Journal of Hydrology 401(1-2): 65-76.

Pidou M, Memon FA, Stephenson T, Jefferson B and Jeffrey $\mathrm{P}$ (2007) Grey water recycling: treatment options and applications. Proceedings of the ICE - Engineering Sustainability 160(ES3): 119-131.

Shouler M, Griggs J and Hall J (1998) Water Conservation. British Research Establishment, Watford, UK. Information Paper.

South Staffordshire Water (2013) Water Use in Your Business Advice and Tips for Saving Water. South Staffordshire Water, Walsall, UK.

UK Met Office (2011) Rainfall Amount Annual Average, 19812010. See http://www.metoffice.gov.uk/climate/uk/ averages/ukmapavge.html (accessed 11/04/2013).

Waggett R and Arotsky C (2006) Water Key Performance Indicators and Benchmarks for Offices and Hotels. Construction Industry Research and Information Association (Ciria), London, UK.

Ward S, Memon FA and Butler D (2012) Performance of a large building rainwater harvesting system. Water Research 46(16): 5127-5134.

2030 Water Resources Group (2009) Charting Our Water Future: Economic Frameworks to Inform Decision-Making. See http://www.2030wrg.org/wp-content/uploads/2012/06/ Charting_Our_Water_Future_Final.pdf (accessed 23/04/ 2014).

Weather Analytics (2012) Weather Data. See http://www. weatheranalytics.com/get-weather-data (accessed 14/03/ 2014).

\section{WHAT DO YOU THINK?}

To discuss this paper, please email up to 500 words to the editor at journals@ice.org.uk. Your contribution will be forwarded to the author(s) for a reply and, if considered appropriate by the editorial panel, will be published as discussion in a future issue of the journal.

Proceedings journals rely entirely on contributions sent in by civil engineering professionals, academics and students. Papers should be 2000-5000 words long (briefing papers should be 1000-2000 words long), with adequate illustrations and references. You can submit your paper online via www.icevirtuallibrary.com/content/journals, where you will also find detailed author guidelines. 